\title{
Coming Back to Life: Voices from Breast Cancer Support Groups in Cuba
}

\author{
By Gloria Giraldo, MPH
}

In Cuba, breast cancer is the most common cancer in women (excluding skin cancer) and the second cause of cancer death in women. The Ministry of Public Health recognizes breast cancer as a major public health problem, and aims to reduce mortality $15 \%$ by 2015 -from the 2004 adjusted mortality rate of 14.1 per 100,000 population to 11.9.[1,2]

Programs are underway to lower mortality and improve survival through improved screening, research on risk factors and new therapies, and broader public education about the importance of early detection. Women in breast cancer support groups are also beginning to play a key role in raising awareness about the disease and about life-after-mastectomy, as well as providing emotional and practical support for each other and their families.

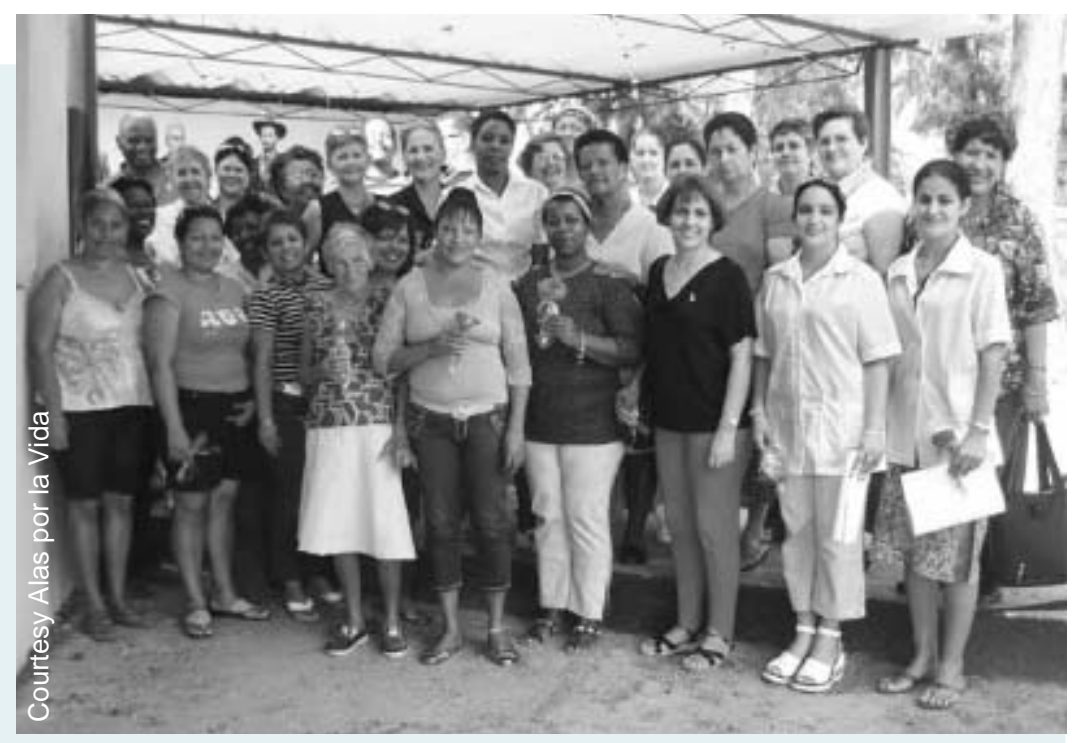

Breast cancer support group in Batabanó.

The first, and now largest, breast cancer support group was started in Havana in 2003 by a few surgeons and their patients who had undergone a radical or partial mastectomies. For these women and the majority diagnosed with breast cancer in Cuba, surgery is the most common shared experience with the disease, and they refer to themselves as 'operadas' (operated on) or 'mastectomizadas' (mastectomized), rather than 'survivors'. However, the group's name, Alas por la Vida (Wings for Life), symbolizes the spirit of hope and determination uniting these women.

\section{MEDICC Review: How did you learn that you had cancer and what was your first reaction?}

Nery Soto (Batabanó, 8-year survivor): I found a lump in my breast that was already quite large. I never imagined it could happen to me. My family doctor referred me to the hospital where I had a biopsy. When the results came back positive, I felt as if I were deaf and blind. I didn't hear anything else, I didn't see anything else. I just started to cry. But my youngest sister was there with me and she and the doctor were very encouraging.

Tania Díaz (Havana, 15-year survivor): I was always very good about getting my clinical breast exams, so when my family doctor found a lump, I was shocked. I'd be dishonest if I said that I was scared of the cancer. The truth is I felt as if someone had just struck me, and my reaction was to strike back: this was a challenge, it was personal. I couldn't allow this thing to beat me.

Idalia Maceira (Cotorro, 3-year survivor): I found the lump myself, and after the biopsy results came back, I couldn't resist, so I opened the envelope and saw that the results were positive. At the doctor's office, I told him I already knew. He put his arm
Today, over 300 women, family members and doctors participate in bimonthly meetings at the Manuel Fajardo ClinicalSurgical Teaching Hospital in Havana. Inspired by this group's experience, breast cancer survivors in other communities are forming their own, supported by the Federation of Cuban Women. MEDICC Review talked with members, physicians and families involved with three groups-in urban Havana, the semi-urban Cotorro municipality on the outskirts of the city, and the rural town of Batabanó, two hours south of the capital-about their experiences with cancer and what the group has meant for them. around my shoulder and told me I needed to have surgery, and right away referred me to an oncologist. My doctors talked to me about conservation surgery but also their concern about other tumors they had found. So I told them that I wanted a radical mastectomy, because I had a 15-year-old son, and I wanted to be with him for as long as I could. They performed the operation, and it was successful.

\section{MEDICC Review: Where have you found your main source of support since your breast cancer diagnosis?}

Yudiht Bravo (Batabanó, 14-year survivor): I was 28 when I found a small lump in my breast. The doctors initially tried conservation surgery, but after radiation, they decided I needed a radical mastectomy. I was divorced at the time, and my son was only six. I thought my life was ending right then and there. Even though I got a lot of support from my family and my doctors and even a psychologist, I was literally scared to death. Until one day I realized that living was going to take more than medicine or treatments, and that I also needed to be more active and more engaged in my own recovery. I started to come back to life. The first year passed and I saw that I was still alive, so I became more 
hopeful. Three years after surgery, I met a new person and we fell in love. We got married and I became pregnant with my daughter. She's been an even stronger force in my life. As I think back about how l've coped, I would say that above all l've found strength in my children and my husband. l've also been a very good patientI go to all my check-ups, follow doctors' orders, and stay in close touch with my oncologist and my surgeon.

Maritza Roselló (Batabanó, 7-year survivor): Family support is fundamental, as well as support from friends and co-workers. In my case, I have two daughters, and from the moment I was diagnosed, they've treated me with such devotion and care. I never wanted to isolate myself from social and political life. I've worked in a canning factory for 27 years, where I'm an occupational safety specialist, and I don't want to retire yet. Not long ago, the doctors found cancer again, this time in my knee. They thought I wouldn't be able to walk normally again, but here I am, walking and even riding my bike to meetings. My orthopedist can't believe it!

Angelina Romeu (Havana, 8-year survivor): I told my doctor, "I have absolute trust in you, do what you need to do." And I did need radical surgery. It was very hard. I'm a professor, and I felt that my professional life was over. But as it turned out, the institute where I work was very supportive, and I was able to modify my job so that I could work from home. I started writing scripts for the educational television series "University for All." I also wrote a book. Regaining a sense of normalcy was very important, as was the support of my son, who took a leave from his job to take care of me during the first few months. He was adamant that nothing was more important to him than taking care of me. My sisters also helped, and l'll never forget my women neighbors; they were so kind. They knew what my favorite dishes were, so one day one would bring me tamales, the next day a different dish. That meant everything to me.

Nery Soto (Batabanó, 7-year survivor): My doctor was very supportive, encouraging me and giving me hope. I have six sisters and one brother, and their love and support have been unconditional, as well as my son's and my husband's. Going through radiation and chemotherapy was very hard, and my sisters, my brother, my son, my husband and my neighbors were all right there with me; we were all fighting this thing together.

MEDICC Review: Speaking of families, how have couples fared under such trying circumstances?

Virginio Rodríguez (Havana, husband of a 5-year survivor): When my wife was diagnosed, we were not yet married. It happened when our lives were filled with such happiness. I had found the woman of my dreams, and she was enjoying being a young grandmother of a two-year-old girl. My first reaction to her diagnosis was to shut down, because my father died of cancer, and I couldn't believe I would have to relive that pain. I thought the world was coming to an end, but I said to myself that either I had the courage to join this fight all the way or leave. I couldn't leave, so I told her that right after the surgery we would get married. I stopped working so I could take care of her every day. I went with her to every single chemo and radiation session. It was heart-wrenching to see the effects of the treatment; the nausea and the weakness in her body. I tried to keep her distracted as much as possible; I would invite her to walk down the beautiful streets of Old Havana. After chemo came the surgery, and after the surgery I was with her when she removed the bandage for the first time. Nothing prepared me for the painful scream she let out. She hugged me and cried, and all my strength seemed to dissolve. But her recovery has been extraordinary. Her entire family — she has seven brothers and sisters-joined forces and helped us get through this.

Ana Díaz (Havana, 5-year survivor): When I learned my diagnosis, I told my husband that we needed to separate, because I couldn't stand not being able to be a good wife and mother. He said, "I don't know what you're going to do with me, but I'm not leaving." He truly became my caretaker during the whole treatment process, the surgery, and then the awkwardness of the prosthesis. There are prostheses made from different materials, and some don't do well in our hot, humid climate. So my husband has become an expert at making my bras. I kid him and tell him he's found a new career as a bra designer.

Israel Yero (Batabanó, husband of an 18-year survivor): The diagnosis was devastating to my wife. She told our daughters that she wasn't going to leave the house ever again, and she wanted to hide from me. After surgery, she was very depressed, and I couldn't find a way to console her. When she was discharged, she didn't stop crying all the way from Havana to Batabanó. But only two to three hours after we arrived, I couldn't believe my ears. She was back on her balcony shouting greetings to our neighbors. That's when her recovery started, as soon as she started chatting with all the neighbors. We soon had a house of full friends and neighbors visiting her. And now, although she walks with a cane and I don't use one, I can't keep up with her! On June 30, we will be celebrating our $40^{\text {th }}$ wedding anniversary.

\section{MEDICC Review: How did you become involved in your support group?}

Alexis Cantero (Havana, surgeon): In 1990 at Havana's Manuel Fajardo Hospital, we created a research group on fine needle aspiration biopsy, a procedure we use most frequently to diagnose breast tumors. We soon realized that after surgery, and even after seeing the hospital psychologist, women faced many fears and unanswered questions. The cancer diagnosis, treatment and surgery were traumatic experiences for most women. Many had thoughts about death and about feeling their bodies had been mutilated. They were uncertain about their futures, careers and families. And most of them had questions about changes in their bodies, not just their physical appearance but hormone changes, and psychological changes too. We realized that we had to offer broader support. In March 2003, we held our first meeting with 17 people, including doctors and staff from the breast care group, patients and family members. At our sixth anniversary meeting in March 2009, 320 people came.

Irmina Aenlle (Cotorro, 3-year survivor): I had a radical mastectomy in 2006. I think I faced the situation courageously; all I really wanted was to keep on living. But I can't deny the psychological damage, especially when I look in the mirror. It may not be so noticeable to the rest of the world, but in front of the mirror l'm always reminded that I lost a part of me-a part I was always told defined my identity as a woman. So, partly as a way to deal with that pain and partly because I've always been active in my community, I thought there must be something I can do for other women. At the time, I was also trying to finish my bachelor's degree in social communication, so I decided to design a social communication strategy that could raise breast cancer survivors' self-esteem by 
becoming health promoters and giving talks in workplaces and schools about the importance of early detection.

I approached the public health department for information about breast cancer in our municipality. I learned that Cotorro is among the 10 municipalities in the country with the highest incidence of breast cancer. I learned of women with breast cancer, and started contacting them, one by one, inviting them to create a support group. I also heard on TV about a support group in Havana, so I got in touch with them to learn about their experiences. We then contacted our local chapter of the Federation of Cuban Women and they embraced our idea. We just held our first event, and we had 56 participants.

Yudiht Bravo (Batabanó, 14-year survivor): I attended one of the Havana group's events, and I thought we should have a similar group in my home town, so I came back and presented the idea to the local Federation chapter. I also started calling women I had known through the years, especially women l'd met in the van that took us to Havana for follow-up treatments. We became a support group more formally in November 2008, and now the directors of the local polyclinic and the maternal-child health program are coming to our monthly meetings. What we hope to achieve in our group is that women feel good about themselves, follow their treatment, learn how to better take care of themselves, and ultimately cultivate hope.

\section{MEDICC Review: How has the support group helped you and other women participating?}

Marta Jorge (Havana, 8-year survivor): Like so many women, I never thought this could happen to me. I've always been a shy person, and knowing I had cancer made me even more withdrawn and even made me feel inferior. One day my husband heard something on the radio about a support group for women who had had mastectomies, and he encouraged me to come and see what it was all about. Joining the group made me feel alive again and helped me see that having cancer was like having any other chronic disease. Meeting other women going through the same experiences has made me feel part of a family.

Tania Díaz (Havana, 15-year survivor): After I had surgery, I thought I was done with this beast; I had taken the bull by the horns and it was over. I didn't even want to talk about cancer anymore. When I was invited to join the group, I declined at first. But after I joined, I learned to open up. The group enabled me to cope with the loss of a very important part of my body, a loss that had affected my self-esteem in a way I didn't want to admit. I've also been able to make new friends with incredibly courageous women, much more courageous than me.

Angelina Romeu (Havana 8-year survivor): After my surgery, all I wanted was to get back to my normal life, to teaching, the work I have always done. I was anxious to open up, to share what I was learning from this experience with other women. Most importantly, I wanted to share what I was learning about cancer and about ways to improve our nutrition and lead healthier lives. The group gives us a space where we can do just that, and now we're also reaching out to healthy women and talking about healthier lifestyles. I feel I have influenced the women in my family, my neighbors and my co-workers with the knowledge l've gained thanks to the group.

Virginio Rodríguez (Havana, husband of 5-year survivor): We say that here in Cuba, everyone is a baseball coach or a doctor, because for every situation and every ailment, everyone is telling you what to do. Sure enough, ever since my wife was diagnosed with cancer, absolutely everyone has medical advice to offer. In the support group, though, she gets reliable information about what and how to eat, and other healthy lifestyle tips. This has been very helpful; for example, she stopped smoking, drinks less coffee and in general tries to lead a healthier life. I consider myself a member of the group. It's very gratifying. And even outside group activities, l've become a promoter of women practicing breast self-exams. I think of it as a tool women have to detect cancer early.

Alexis Cantero (Havana, surgeon): In our culture, women's breasts have a strong connotation of femininity and physical attractiveness. And they're a part of the body intrinsically associated with sexuality. The group gives women a space where they can talk about sexuality, gender issues, family violence, alternative and natural medicine, and even medical ethics. We often invite guest lecturers on topics the women select, with open questions-and-answers, followed by a session in which women share their reflections about living with cancer or being a cancer survivor. We always end with a guest artist or performer. We've received a lot of support from musicians, painters and other artists. In 2006, some of Cuba's best-known painters organized a special exhibit related to breast cancer, which was great for raising public awareness.

Breast cancer survivors are extremely courageous women with a powerful healing message. They've become spokeswomen for the early detection program. After all, who can better speak about breast cancer? Their message empowers healthy women as well as other cancer patients and survivors. -1 -

\section{References \& Notes}

1. Ministry of Public Health (CU). Proyecciones de la salud pública en Cuba para el 2015. Havana: Editorial Ciencias Médicas; 2006, p. 34

2. According to the Ministry's 2007 Health Statistical Yearbook, the provisional breast cancer mortality rate per 100,000 women was 23.7 in 2007. See Ministry of Public Health (CU). Anuario Estadístico de Salud 2007 [monograph on the Internet]; [cited 2009 Jun 16]. Available from: http://www.sld.cu/galerias/pdf/ sitios/dne/anuario_estadistico_de_salud_2007_e.pdf 